Check for updates

The BMJ

Cite this as: BMJ 2021;373:n1033 http://dx.doi.org/10.1136/bmj.n1033 Published: 21 April 2021

\title{
Covid-19: Government's shielding scheme failed thousands of clinically extremely vulnerable people, say MPs
}

\section{Elisabeth Mahase}

At the start of the covid-19 pandemic the UK government failed to reach up to 800 ooo clinically extremely vulnerable people who had been added to the shielding list, meaning they could not get support such as food parcels, a report by MPs has said. ${ }^{1}$

The Public Accounts Committee found that nearly half of these people were not reached because of missing or incorrect telephone numbers in NHS records. Local authorities were then asked to contact the people, but the Ministry of Housing, Communities and Local Government still does not know whether the 800 ooo people were reached.

The report said, "The programme suffered from the problems of poor data and a lack of joined-up systems that we see all too often in government programmes. As a result, government took too long to identify some clinically vulnerable people at a time when their need was urgent."

\section{Growing shielding list}

As well as difficulties in reaching the identified vulnerable people to provide them with support, some organisational and data problems delayed addition of people to the shielding list.

NHS Digital created the first iteration of the list of 900 ooo people within two days, using easily accessible data sources such as hospital, maternity, and prescribed medicines data.

But three weeks after shielding started an extra 420 ooo people (making a total of 1.3 million) were then added from general practice data. This delay was because NHS Digital had to work with GP IT system providers to gather the data. GPs and hospital doctors were then asked to review the list and use their clinical judgment to add or remove people. This led to the list rising to 1.8 million people by 18 April and then 2.2 million by 7 May.

Depending on the area, list sizes grew by between $15 \%$ (Carlisle) and 352\% (Hounslow), with an average increase across local authorities of $73 \%$. A total of 33 authorities saw their list sizes more than double. The committee said this was an "unacceptable level of variation in local additions" and suggested it could have created a postcode lottery of support.

As people were added to the list, NHS England and NHS Improvement sent letters to people advising them to shield, but charities told the committee that there were delays in people receiving these letters, which put them at risk of infection and caused distress and delays in accessing support.

In February 2021 an additional 1.7 million people were then classified as clinically extremely vulnerable and advised to shield because of a better understanding of risk factors. The health department acknowledged that its purely clinical approach to vulnerability had previously omitted key characteristics such as ethnicity, postcode, and body mass index.

The committee has advised the health department to ensure that in the future it considers non-clinical factors and personal circumstances beyond susceptibility to disease when identifying vulnerable people and the support they need.

Its other recommendations to the government included that it must ensure that local authorities continue to have the capacity to support the needs of clinically extremely vulnerable people and that it must set out a detailed plan on how it will join up NHS data systems and improve access to them. The health department and NHS Digital must also provide a detailed explanation for the local variation in growth of the shielded patient lists.

\section{House of Commons Committee of Public Accounts. Covid 19: supporting the vulnerable during lockdown. 21 Apr 2021. https://committees.parlia- ment.uk/work/1003/covid19-supporting-the-vulnerable-during-lockdown.}

This article is made freely available for use in accordance with BMJ's website terms and conditions for the duration of the covid-19 pandemic or until otherwise determined by BMJ. You may use, download and print the article for any lawful, non-commercial purpose (including text and data mining) provided that all copyright notices and trade marks are retained. 